\title{
TRENDS AND PERSPECTIVES OF THE ZIKA PANDEMIC: A SHORT REVIEW
}

\author{
Baburajan Radha ${ }^{1 *}$, Gnanaraj Muniraj ${ }^{2}$ \\ ${ }^{1}$ MVK Hospital- Hitech Diagnostic laboratory, Tanjavur-02, Tamil Nadu, India. \\ ${ }^{2}$ Department of Plant Morphology and Algology, School of Biological Sciences, Madurai Kamaraj University, \\ Madurai-21, Tamil Nadu, India.
}

*Corresponding Author Email: babumkubct@gmail.com

\begin{abstract}
Zika virus infections become an alarming current global threat. In spite of the increasing morbidity and mortality being reported around the world, there is no official vaccine declared against these infections yet. Hence, this review elucidates the various recent studies conducted in different animal models and cell lines, in the context of, disease etiology, epidemiology, serological and molecular diagnosis, disease complications, viral proliferation mechanisms, and treatment strategies. This paper also attempts to give certain critique on these diverse trends.
\end{abstract}

\section{KEY WORDS}

Zika virus, Epidemiology, Neurotropism, Animal models, Anti-viral therapies, and Vaccines.

\section{INTRODUCTION}

ZIKA Virus (ZIKV) was first discovered among the Rhesus monkeys of the Zika forests of Uganda in 1947 [1]. The first human case was reported almost six years later in 1953 in Nigeria [2]. Now the ZIKV infections sweep the entire world with numerous cases reported in the Americas, Africa, Asia-pacific countries, and, even certain 'imported' cases by the travelers and migrants to Europe and Oceania [FIGURE:1] [3-4]. There were enormous concerns on the possible transmission of ZIKV infections during the Rio Olympic and Paralympic games. [5-6]

The mode of this infection is vector-borne, through the mosquito Aedes aegypti. The reports on vector competency of another mosquito species for ZIKV are controversial [7-10]. Sexual transmission of ZIKV is also reported [11]. An interesting case study [12] reports an asymptomatic ZIKV positive male, after the subject transmitted the infection to his female sexual partner, who developed major ZIKV symptoms. In addition, transmission via platelet transfusion [13] is also reported, resulted in monitoring of blood transfusion for ZIGV infections [14].
ZIKV along with Dengue virus (DENV) and Chikungunya virus (CHIKV) belong to the Flavivirus genus and the Flaviviridae family. This infection among pregnant women would result ('Vertical transmission') in Microcephaly and other brain abnormalities of the neonate [FIGURES:2-3] [15]. In adults, it causes Guillain-Barre Syndrome [16-19]. Other physiological problems such as Hearing loss in microcephalic infants [20], Abnormal heart rate and Blood pressure [21] and other cardiac problems [22] also are reported to be possible consequences.

Anthony R. Mawson-2016 [23] in their dissident hypothesis, state that higher retinoid concentration in liver could be the cause of the reported ZIKV complications and Guillain-Barré syndrome. They suggest the monitoring and comparison of retinoid levels and expression profiles among the microcephalic and control neonates. Similar view, albeit at genetic level, was expressed by Ashutosh Kumar et al. [24] Interestingly, there are no vaccines or anti-viral therapies announced so far by the WHO and the measures available in our hands are prevention and control strategies on spread of these infections. 
Reproductive planning [25-26] and Abortion [27] also are seriously considered.

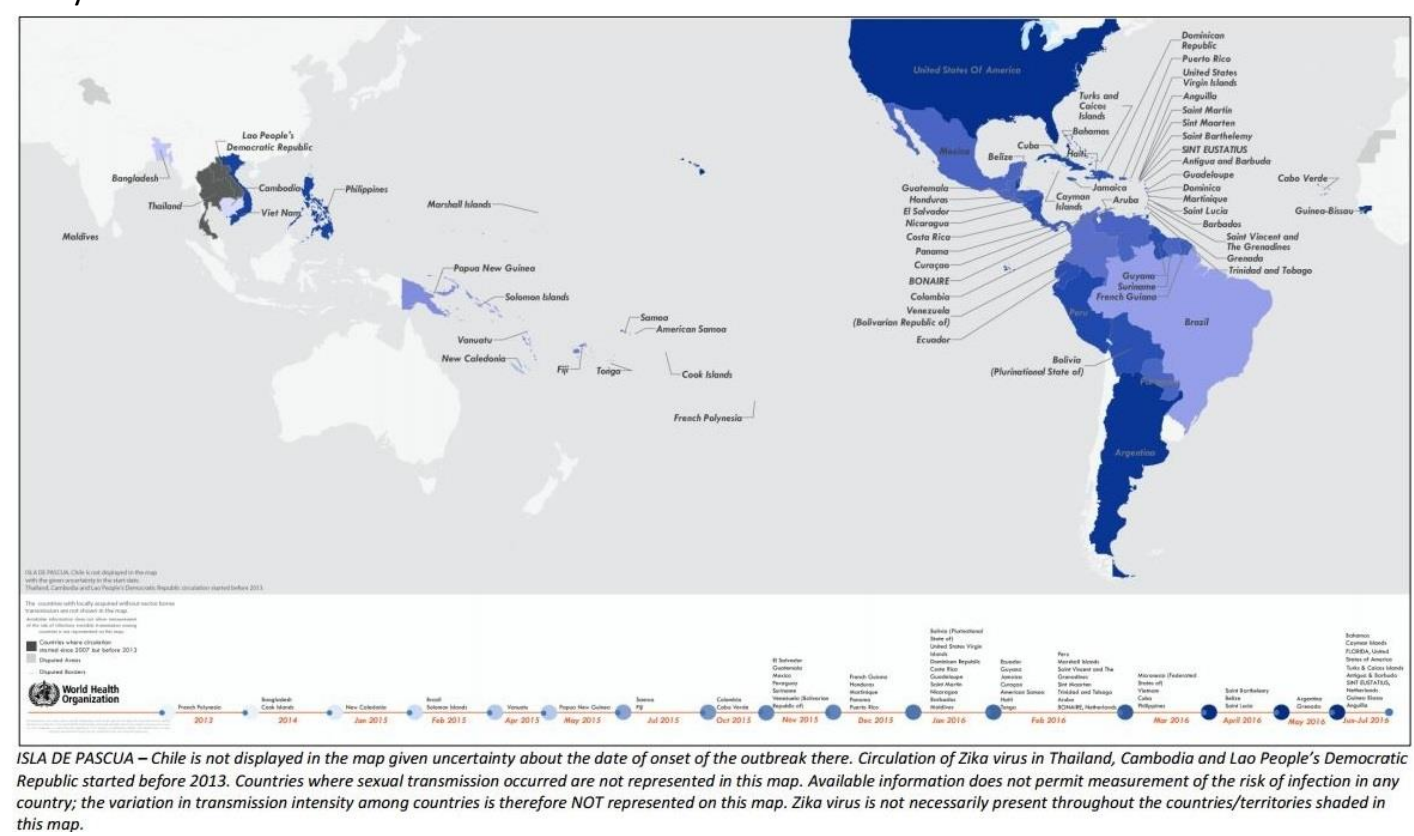

FIGURE:1. Global Spread of Zika virus from 2013-2016. (Source: www.WHO.int)

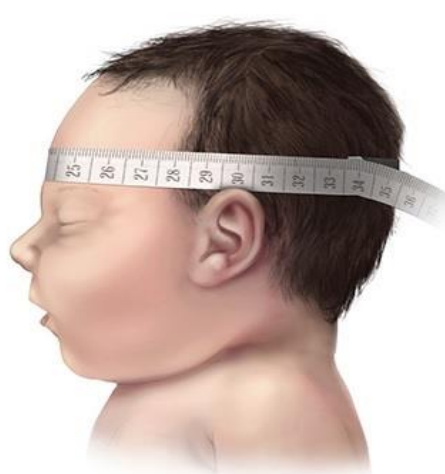

Baby with Typical Head Size

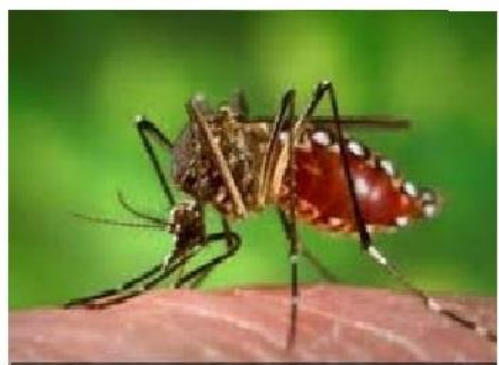

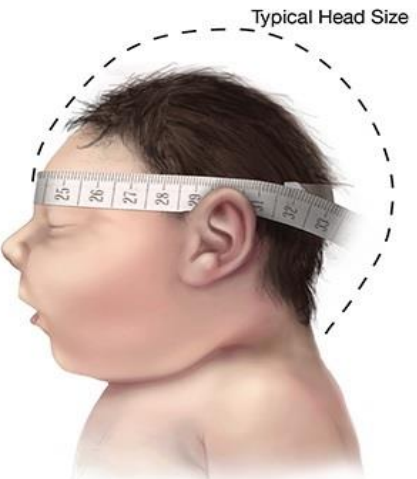

Baby with Microcephaly

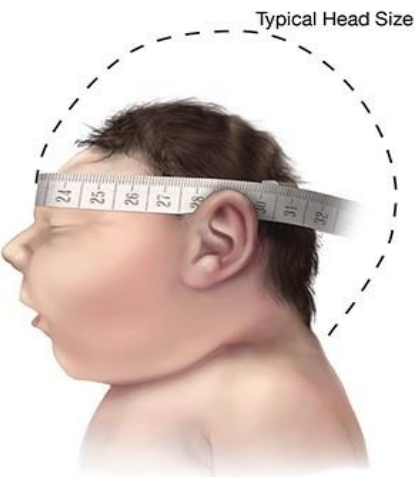

Baby with Severe Microcephaly

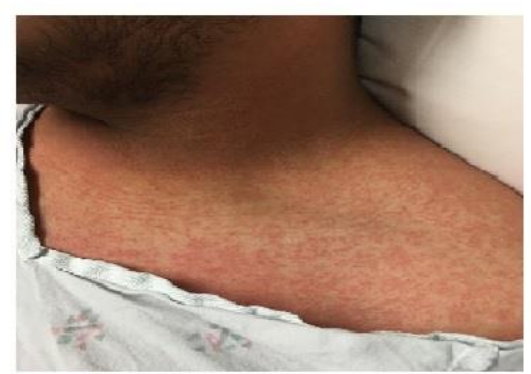

FIGURE:2. Top. Measurement of Microcephaly in Neonates (Source: www.cdc.gov).Bottom. Left. Aedes aegypti Mosquito (Source: www.cdc.gov).Right. Typical Maculopapular rash of ZIKV infections. (Adopted from Kristi L.Koenig et al). 


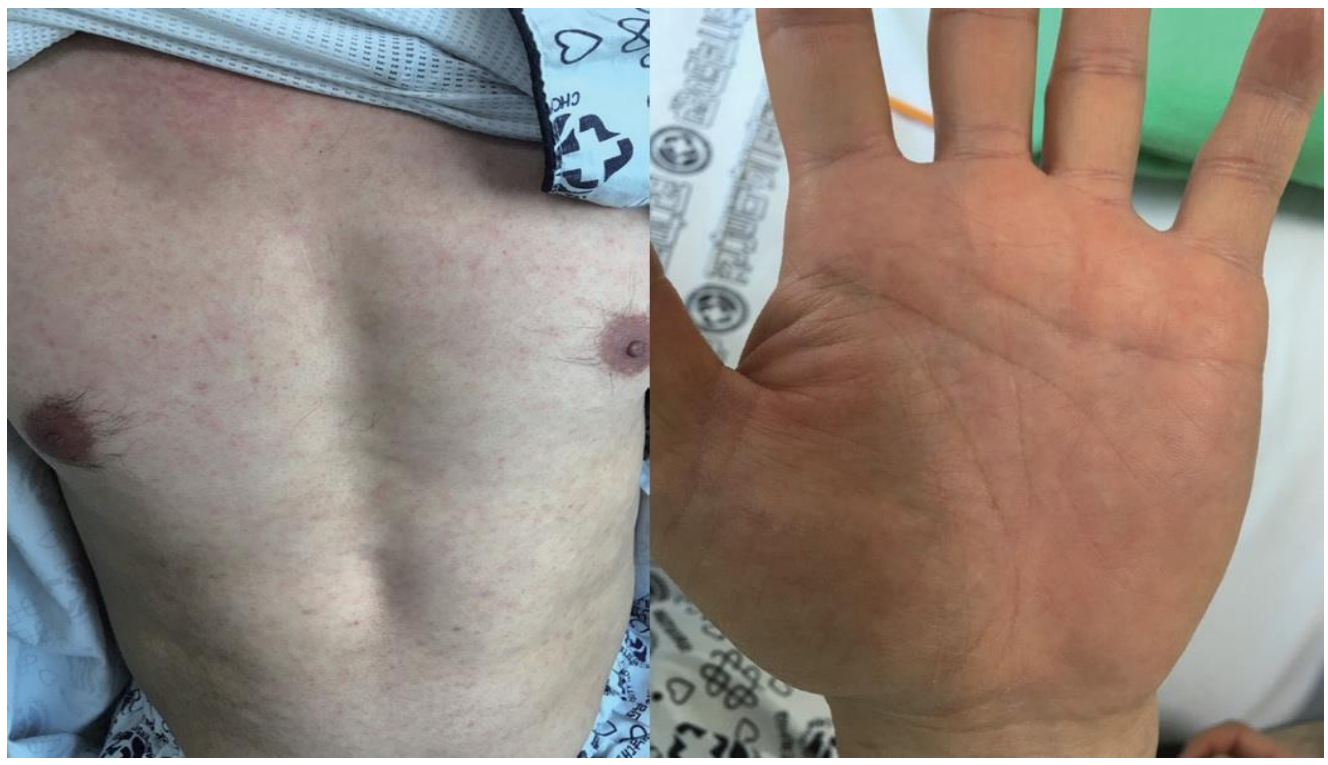

Figure:3. Clinical manifestation and virus shedding. Maculopapular rash on the trunk and palm. (Adopted from Debora Ferreira Barreto-Vieira et al., 2016).

\section{TRENDS ON DETECTION AND DIAGNOSIS:}

The ZIKV is reported to be diagnosable in Urine, Saliva, Serum and Semen samples. Nicastri E et al., [28] report the presence of ZIKV RNA in Cerebrospinal fluid (CSF). Presence of ZIKV RNA in tears is also reported in Rodent model [29]. Debora Ferreira Barreto-Vieira et al., [30] with their study report fine ultra-structure of ZIKV [FIGURE:4]. Rémi N Charrel et al., [31] in their extensive review describe various common clinical and molecular diagnostic parameters in different biological fluids utilized worldwide [TABLES:1-2]. As conventional serological diagnostic methods are limited by the crossreactivity among the Flavi viruses, PCR- based methods are usually preferred to them. Xu MY et al., [32] developed an YBR Green based real-time RT-PCR for the detection of ZIKV RNA in cell sample. This technique analyses the replication of ZIKV in different times within the living cells. The lower limit of this method is 1PFU per $\mathrm{ml}$.

Jinzhao Song et al., [33] developed a simple, costeffective and accurate method for sample collection and DNA amplification which could selectively identify ZIKV with the sensitivity limit of 5 PFUs. This kit could be very useful in distant areas where no facilities are available. The underlying method combines reversetranscription loop-mediated, isothermal amplification (RT-LAMP) assay with a Point- of -Care (POC) cassette for the detection. [ FIGURES:5-6]
Another technique combining the LAMP principle and AC susceptometry for the detection of ZIKV oligonucleotides is reported [34]. This method could detect the oligonucleotides as low as 1aM (Attomolar). Calvo EP [35] et al., devised a PCR method with the second-round amplification of RNAs with specific inner primers for the specific detection of each viral RNAs during DENV-CHIKV-ZIKV co infections among febrile patients. The cross-reactivity of DENV sera with ZIKV is also studied using focus reduction neutralization tests (FRNTs) by Lalitha Priyamvada et al.,2016 [36]. The FRNT titres of two acute dengue sera (\#33 and \#39) and one naïve Flavivirus sera (\#21) against ZIKV were measured [FIGURE:7]. With their experiment with ZIKV infecting the human Fc $\gamma R$-bearing monocytic cell line, U937 they suggest that DENV antibodies could also enhance the ZIKV infections.

Myrna C. Bonaldo et al., [37] report the isolation of ZIKA viral particles from saliva and urine of the patients from the state of Rio de Janiero, Brazil. The urine and saliva samples from patients were inoculated in Vero cell cultures. RNA isolation and quantification were performed by RT-qPCR. ZIKV was isolated from both saliva and urine samples [FIGURE:8]. Complete genomic sequence was obtained and phylogenetic analyses revealed similarities of the isolates with that of various South American epidemics [FIGURE:9]. This report recommends the utility of urine and saliva 
samples to be the tools for the effective diagnosis of ZIKV.

Dhiraj Acharya et al., [38] 2016 report an Electrogenerated chemiluminescence (ECL) based method to detect ZIKV from body fluids. In this method, the virus (lower limit is $1 \mathrm{PFU}$ in $100 \mu \mathrm{L}$ sample) is trapped between ELC labeled -polystyrene beads (PSBs) and magnetic beads conjugated with virus specific antibodies [FIGURE:10].

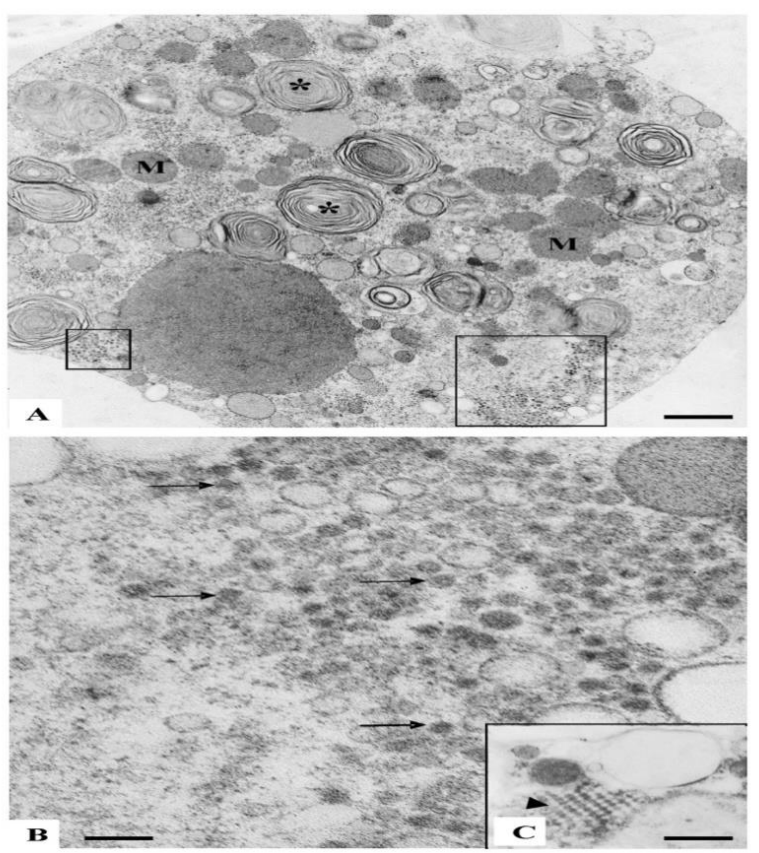

Figure:4 Vero cells six days' post inoculation with a human blood serum sample positive for ZIKV. (A) Infected Vero cell presenting numerous myelin figures (*), vacuoles, and clusters of ZIKV particles (marked areas). (B) ZIKV particles (arrows). (C) regularly arranged viral nucleocapsids (Arrow head). (Adopted from Debora Ferreira Barreto-Vieira et al., 2016).

\begin{tabular}{|c|c|c|c|c|}
\hline $\begin{array}{l}\text { Country } \\
\text { imported } \\
\text { into }\end{array}$ & $\begin{array}{c}\text { Country } \\
\text { or island } \\
\text { imported } \\
\text { from }\end{array}$ & $\begin{array}{l}\text { No. of } \\
\text { human } \\
\text { cases }\end{array}$ & $\begin{array}{l}\text { Zika virus RNA } \\
\text { detection results }\end{array}$ & $\begin{array}{l}\text { Positive Zika virus serology } \\
\text { results }\end{array}$ \\
\hline Australia & $\begin{array}{l}\text { Cook } \\
\text { Islands }\end{array}$ & 1 & Serum-positive & IgG, IgM seroconversion \\
\hline Australia & Indonesia & 1 & Serum-positive & - \\
\hline Canada & Thailand & 1 & $\begin{array}{l}\text { Serum-, urine- } \\
\text { positive }\end{array}$ & $\begin{array}{l}\text { IgM: seroconversion in } \\
\text { neutralization assay }\end{array}$ \\
\hline Finland & Maldives & 1 & Urine-positive & Not tested \\
\hline Germany & Thailand & 1 & Serum-negative & $\lg M, \operatorname{lgG}$ \\
\hline Germany & Indonesia & 1 & Serum-negative & $\begin{array}{l}\text { IgG, IgM seroconversion; } \\
\text { neutralization assay }\end{array}$ \\
\hline Italy & Brazil & 1 & - & $\begin{array}{l}\text { IgM; IgG seroconversion; } \\
\text { seroconversion neutralization } \\
\text { assay }\end{array}$ \\
\hline Italy & $\begin{array}{l}\text { French } \\
\text { Polynesia }\end{array}$ & 2 & Serum-positive & IgG, IgM seroconversion \\
\hline Japan & Thailand & 1 & $\begin{array}{l}\text { Serum- } \\
\text { equivocal,a } \\
\text { urine-positive }\end{array}$ & $\lg M$ \\
\hline Japan & $\begin{array}{l}\text { French } \\
\text { Polynesia }\end{array}$ & 2 & $\begin{array}{l}\text { Serum-, urine- } \\
\text { positive }\end{array}$ & $\begin{array}{l}\text { IgM, seroconversion neutralization } \\
\text { assay }\end{array}$ \\
\hline Norway & $\begin{array}{l}\text { French } \\
\text { Polynesia }\end{array}$ & 1 & Serum-positive & IgG, IgM seroconversion \\
\hline $\begin{array}{l}\text { United } \\
\text { States }\end{array}$ & $\begin{array}{l}\text { French } \\
\text { Polynesia }\end{array}$ & 1 & - & IgM; IgG seroconversion \\
\hline
\end{tabular}

Table:01 Various ZIKV diagnostic results. (Adopted from Rémi N Charrel et al.,2016). 


\begin{tabular}{|c|c|c|c|c|c|c|c|}
\hline $\begin{array}{l}\text { Author (year) of } \\
\text { published PCR assay }\end{array}$ & PCR target & PCR technique & $\begin{array}{l}\text { Amplicon } \\
\text { size (bp) }\end{array}$ & $\begin{array}{l}\text { Zika virus } \\
\text { lineage } \\
\text { analytical }\end{array}$ & $\begin{array}{l}\text { Zika virus } \\
\text { lineage } \\
\text { field }\end{array}$ & $\begin{array}{l}\text { No. of human patients } \\
\text { tested in studies }\end{array}$ & $\begin{array}{l}\text { Sample types } \\
\text { positive in } \\
\text { field }\end{array}$ \\
\hline Lanciotti et al. (2008) & $\begin{array}{l}\text { Zika virus prM/E, } \\
\text { target } 1\end{array}$ & Hydrolysis probe & 76 & Asian, African & Asian & $\begin{array}{l}>200 \text { (combined } \\
\text { set) }\end{array}$ & $\begin{array}{l}\text { Serum, urine, } \\
\text { amniotic fluid }\end{array}$ \\
\hline Lanciotti et al. (2008) & $\begin{array}{l}\text { Zika virus } \mathrm{E} \text {, } \\
\text { target } 2\end{array}$ & Hydrolysis probe & 76 & Asian, African & Asian & $\begin{array}{l}>200 \text { (combined } \\
\text { set) }\end{array}$ & $\begin{array}{l}\text { Serum, urine, } \\
\text { amniotic fluid }\end{array}$ \\
\hline Faye et al. (2013) & Zika virus NS5 & $\begin{array}{l}\text { Locked nucleic } \\
\text { acid probe }\end{array}$ & 102 & Asian, African & African & $\begin{array}{c}3 \text { (B Rockx, personal } \\
\text { communication, } \\
\text { February 2016) }\end{array}$ & Serum \\
\hline Tappe et al. (2014) & Zika virus NS3 & Hydrolysis probe & 94 & Asian & Asian & 5 & Serum \\
\hline Faye et al. (2008) & Zika virus E & Conventional & 364 & African & Asian & $>15$ (combined set) & Serum \\
\hline Pyke et al. (2014) & Zika virus NS1 & Hydrolysis probe & 65 & Asian & Asian & 1 & Serum \\
\hline Pyke et al. (2014) & Zika virus E & Hydrolysis probe & 71 & Asian & Asian & 1 & Serum \\
\hline Moureau et al. (2007) & Flavivirus NS5 & $\begin{array}{l}\text { SYBR }{ }^{\circ} \text {-green- } \\
\text { based }\end{array}$ & $269-272$ & African & Asian & 2 & Serum, urine \\
\hline Kuno et al. (1998) & Flavivirus NS5 & Conventional & 1079 & Asian, African & Asian & 51 & Serum \\
\hline Scaramozzino et al. (2001) & Flavivirus NS5 & $\begin{array}{l}\text { Conventional } \\
\text { (semi-nested) }\end{array}$ & 220 & African & Asian & $\begin{array}{l}1 \text { (L Barzon, personal } \\
\text { communication, } \\
\text { February 2016) }\end{array}$ & Serum, urine \\
\hline $\begin{array}{l}\text { Maher-Sturgess et al. } \\
(2008)\end{array}$ & Flavivirus NS5 & Conventional & 800 & African & Asian & 1 & Serum \\
\hline Ayers et al. (2006) & Flavivirus NS5 & Conventional & 863 & - & Asian & 1 & $\begin{array}{l}\text { Serum, urine, } \\
\text { nasopharynx }\end{array}$ \\
\hline
\end{tabular}

Table:02. Various ZIKV lineages and diagnostic markers (Adopted from Rémi N Charrel et al.,2016)
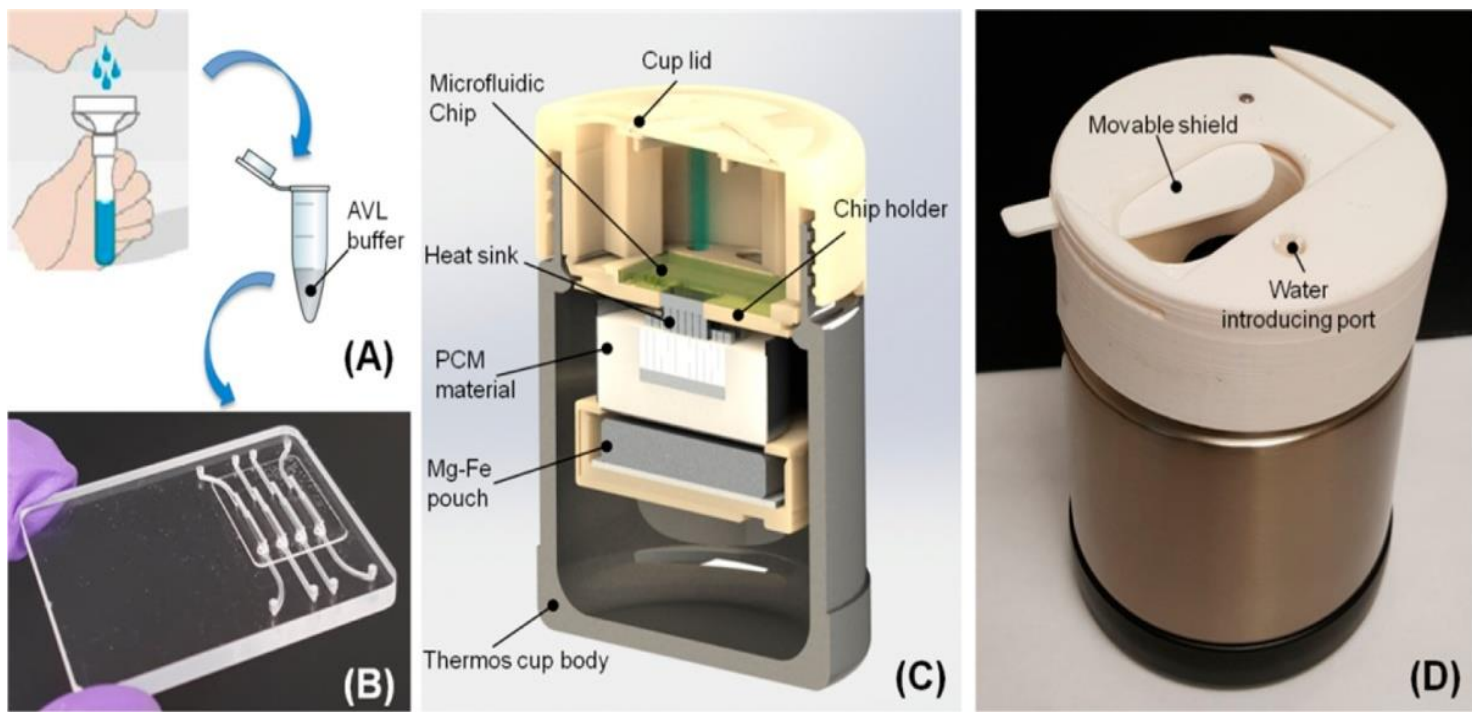

Figure:5 (A) Schematic of saliva sample preparation. Saliva samples are first collected in a saliva collection tube and then lysed in Qiagen binding/ lysis (AVL) buffer. (B) The lysed sample is filtered through the isolation membrane of our microfluidic cassette for nucleic acid extraction. (C) Exploded view of the chemically heated cup. The cup consists of a thermos cup body, a 3D-printed cup lid, a chip holder, PCM material, heat sink and single-use $\mathrm{Mg}-\mathrm{Fe}$ alloy pack heat source. (D) A photograph of the chemically heated cup for point of care molecular diagnostics of ZIKV. (Adopted from: Jinzhao Song et al., 2016). 


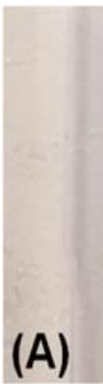

1
2

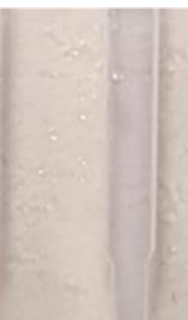

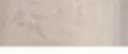

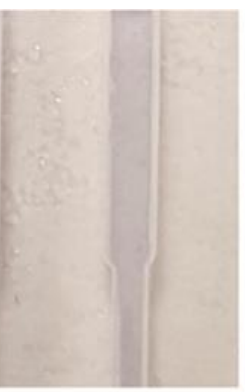

3

4

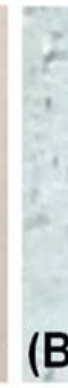

(B)

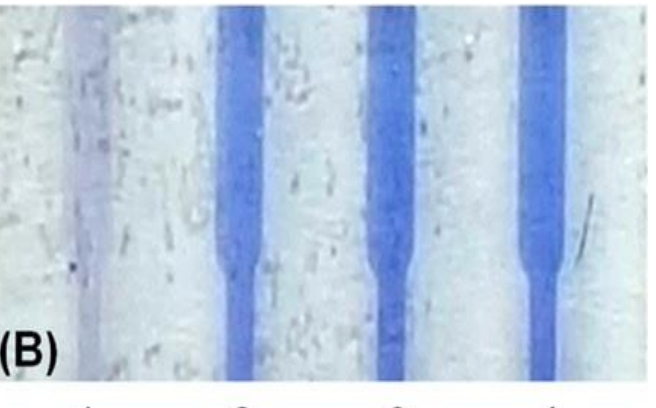

12
34

Figure :6 Photographs of the isothermal amplification reactors (A) before and (B) after $\mathbf{4 0}$ min incubation in the chemically heated cup. Leuco crystal violet dye is used as an amplification indicator. Amplification reactors 1,2 , 3, and 4 contain 0, 5, 50, and 500 PFU of ZIKV (Adopted from: Jinzhao Song et al., 2016).

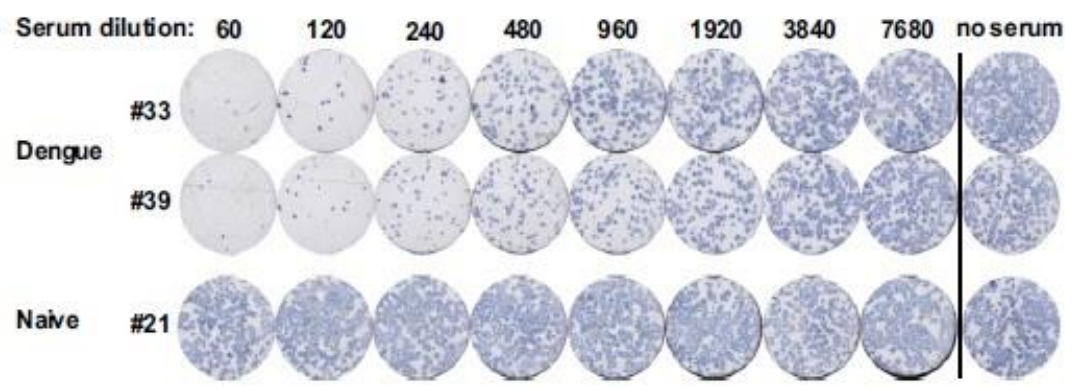

Figure:7 The Neutralization of ZIKV by DENV sera in different dilutions (Adopted by Piriyamvada et al.,2016).
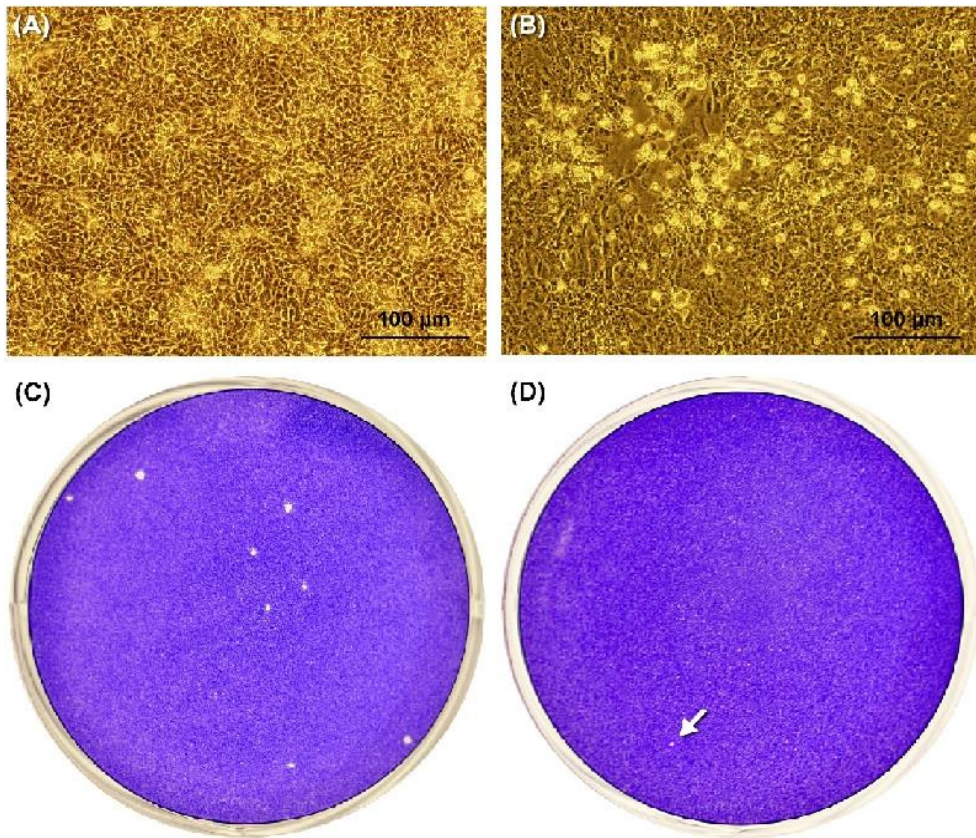

Figure:8 Isolation of Zika virus in Vero cell from the saliva of patient 6. Phase contrast optical microscopy of culture flasks containing (A) Mock-infected Vero cells and (B) saliva-infected Vero cells presenting a clear visible cytopathic effect. Viral plaque detection in saliva (C) and urine (D). The white arrow shows the unique viral plaque detected in the urine sample. (Adopted from Myrna C. Bonaldo et al., 2016). 


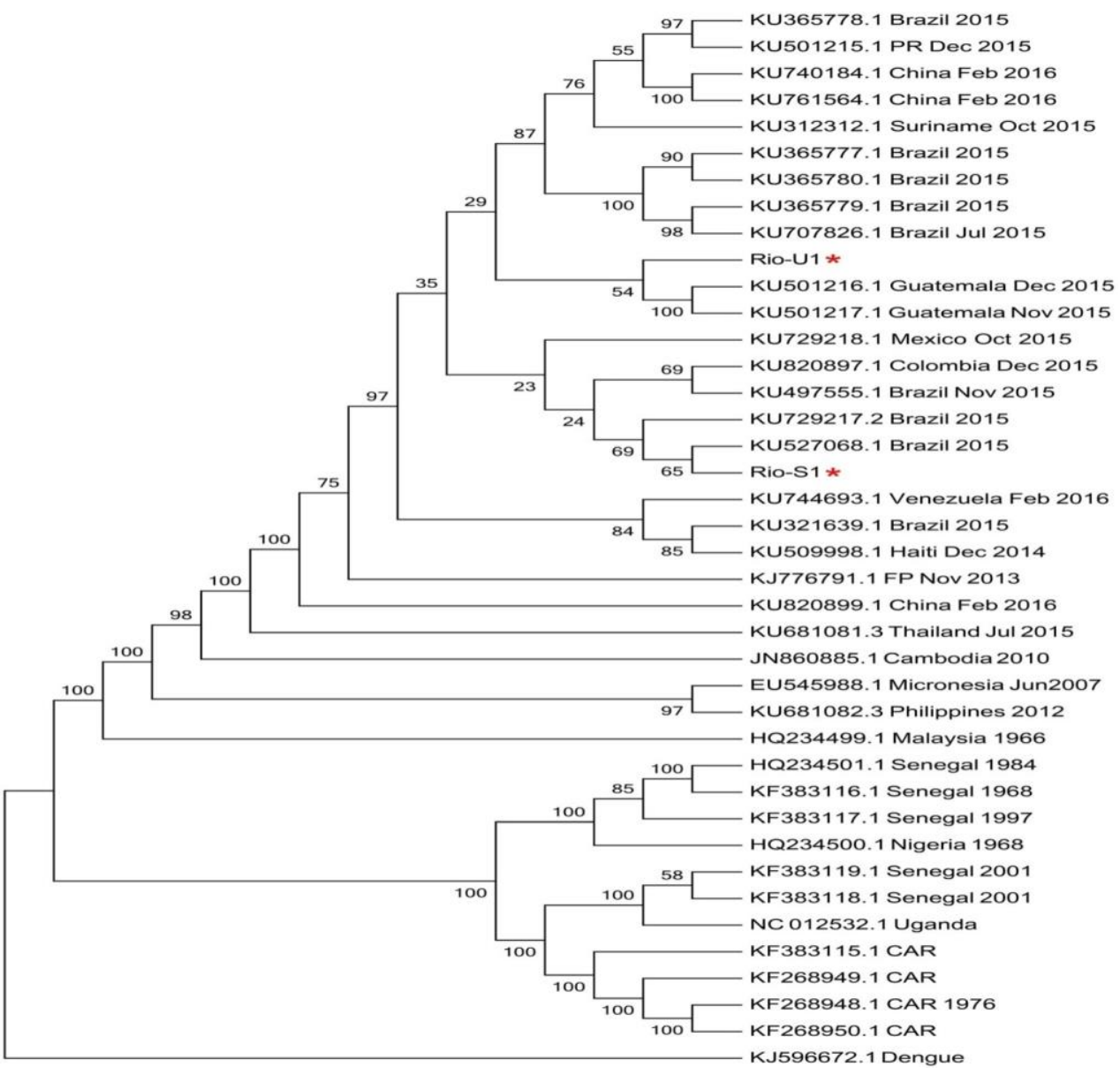

Figure: 9. Phylogenetic analyses of strains Rio-U1 and Rio-S1 marked with * $(R e d)$ with other strains of various epidemics. (Adopted from Myrna C. Bonaldo et al., 2016).

A

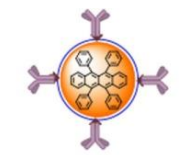

PSB(RUB) avidinbiotinylated antibody<smiles>C[13CH][13CH3]</smiles>

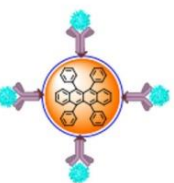

PSB(RUB) avidinbiotinylated antibody<virus
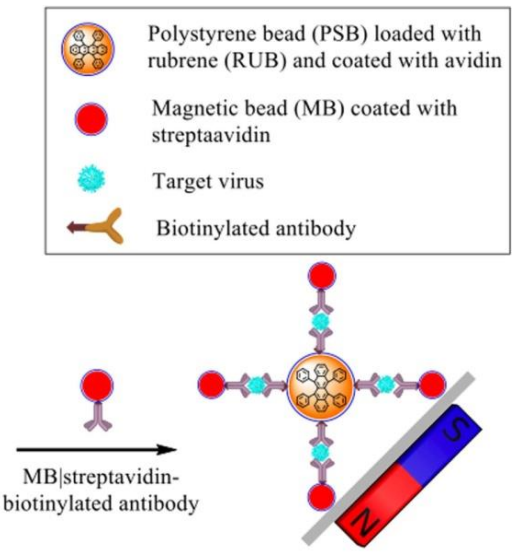

PSB $<$ virus $>\mathrm{MB}$ aggregates

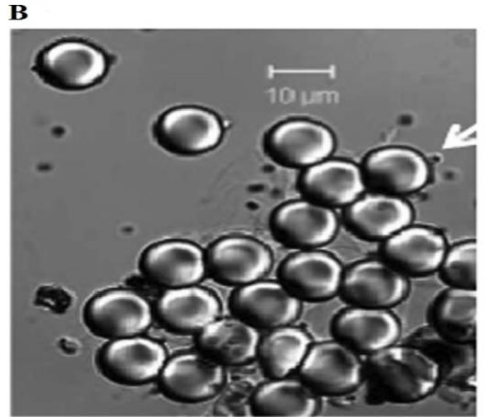

Figure: 10 A: Diagram representing the procedures for the detection of Virus. B: A phase-contrast image of PSB $<$ ZIKV > MB aggregates showing the binding of anti-ZV2-MB (1 $\mu \mathrm{m}$ diameter, arrow) to the surface of anti-ZV2PSB (10 $\mu \mathrm{m}$ diameter) in the presence of ZIKV. (Adopted from Dhiraj Acharya et al., 2016)

\section{EVIDENCES FROM GENETIC AND SYSTEM BIOLOGICAL APPROACHES:}

The genetic diversity of ZIKV strains from various epidemics is widely reported [39-40]. Meghan May et al. [41], using system biological approach, report the specific diversity of $\mathrm{O}$-linked glycome across various ZIGV species. Sang-Im Yun et al [42]. report the complete RNA genome sequence of three genetically distinct ZIKV strains MR-766 (Uganda,1947), P6-740 
(Malaysia 1966) and PRVABC-59(Asian derived origin from Peurto Rico,2015).

In addition, G.Piorkowski et al [43] report the complete coding sequences of ZIKV isolated from the place Martinique and named 'ZIKAV strain MRS_OPY_Martinique_PaRi_2015'. The open reading frame (ORF) was found to comprise three structural proteins (Capsid, Pre-membrane/ Membrane, and Envelope) and seven nonstructural proteins (NS1, NS2A, NS2B, NS3, NS4A, NS4B and NS5). Using Maximum Likelihood analyses in MEGA6 they suggest that it is of Asian lineage and shares nucleotide similarity with strains isolated from French Polynesia and Brazil. An interesting work by Formijn van Hemert et al [44] report the unique Codon usages within ZIKV, which could translate into various key molecules of viral mechanisms. Another similar work [45] is reported in the context of Microcephaly

Meanwhile, construction of bioinformatic tools for the analyses of ZIKV RNA Sequence data [46] and epitope analyses for vaccine development [47] also are reported. Similarly, Dikhit MR et al., [48] using Immuno-Informatics identified various MHC Class 1 restricted epitopes in Capsid, Envelope and NS proteins of ZIKV, against which, effective vaccine could be developed. Alam et al., [49] used similar approaches and found epitopes in Envelope glycoproteins. In fact, certain monoclonal antibodies (mAbs) against ZIKV Envelope proteins were reported [50] to be effective against various ZIKV strains of African, American and Asian origin. By virtue of cross-reactivity mAbs against DENV Envelope epitope which were isolated from the Dengue patients also found to be protective against ZIKV [51]. This conclusion is in contradiction with earlier [32] evidences, which suggest that DENV mAbs could aggravate ZIKV infections.
In addition, Victor Satler Pylro et al., [52] report the creation of the database 'ZIKV - CDB' for analyzing the small noncoding RNAs (sncRNAs) involved in the pathogenesis of ZIKV.

\section{ON PATHOGENESIS:}

Various bioinformatic and experimental studies report the link between ZIKV infections and microcephaly in neonates. Using transcriptomic analysis, Gene ontology, and pathway analyses Alyssa J. Rolfe et al., [53] report that human neural progenitor cells (hNPCs) are the high targets of ZIKV, along with the activation of numerous pro-inflammatory cascades. This result is confirmed by another report [54] with the Puerto Ricon ZIKV stain PRVABC59, suggesting the fetal primary human fetal neural progenitors (hNPs) to be the primary targets during neural infections [FIGURE:11]. In addition, Feiran Zhang et al., [55] with their Gene expression and Bioinformatic approaches on Asian (ZIKVC), African (ZIKVM), and DENV strains report the strain-specific influence of important hNPCs pathways. $\mathrm{Li} \mathrm{H}$ et al., [56] also generated similar results from their study.

Another study [57] upon Neuroblastoma (NB) cell lines exposed to the PRVABC59 strain, report that undifferentiated are much susceptible to ZIKV infections than the differentiated neurons. This result explains the major absence of ZIKV complications in adults. In this study, cell lines of male origin such as CRL- 2267, CCL-127, CRL-2271 and SMS-KCNR, of female origin such as CRL-2266, and CRL- 2149, and terminally differentiated olfactory neuroblastoma cell lines such as T-268 and JFEN were used [FIGURE.12]. Altogether these studies explain the pathogenesis behind the onset and aggravation of Microcaphaly among neonates. 
A

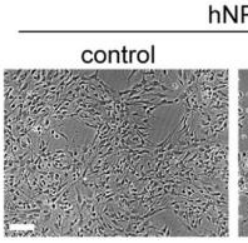

B

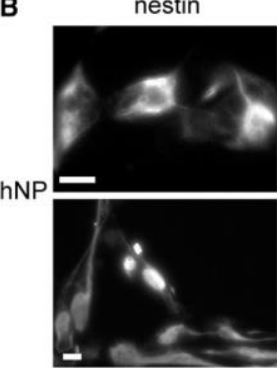

C

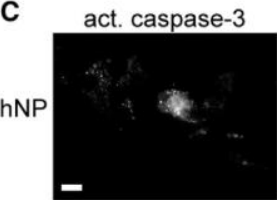

NP

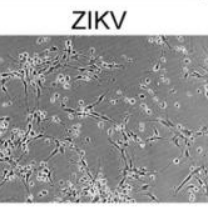

ZIKV-E

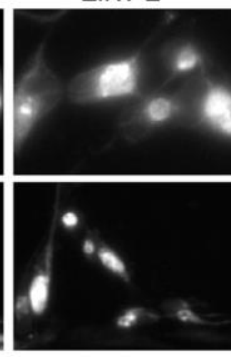

ZIKV-E

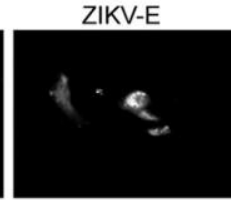

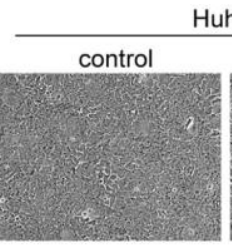

Hoescht

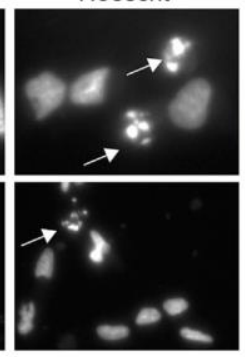

DNA

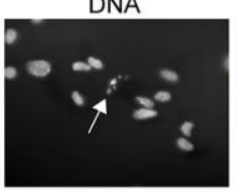

Huh7.5

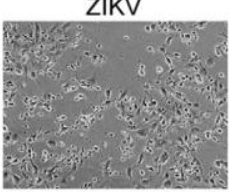

merge

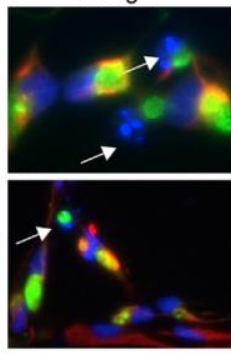

merge

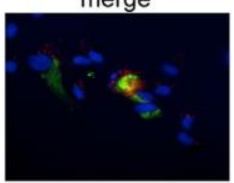

Figure:11 ZIKV Is Partially Cytopathic, but Poorly Immunogenic, in hNPs (A) Bright-field microscopy images of ZIKVinduced cytopathic effects in hNPs and Huh7.5 cells 4 days after infection. (B) Indirect immunofluorescence of ZIKV infection in hNPs. Cells were stained with antibody in order to detect ZIKV E protein and Hoechst DNA stain. (C) Indirect immunofluorescence of ZIKV infection in hNPs. Cells were stained antibodies in order to detect ZIKV E protein and activated caspase 3. (B and C) White arrows highlight pyknotic nuclei. (Adopted from Natasha W. Hanners et al).

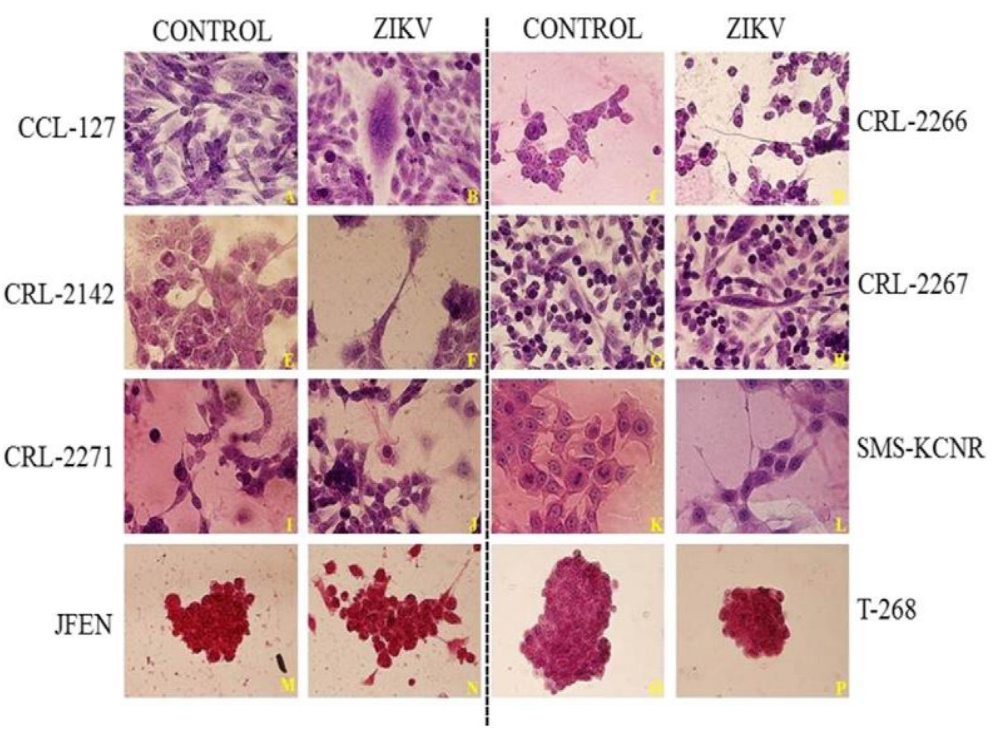

Figure:12. Morphological analyses by utilizing H\&E staining. (Top row, left to right) A) CCL-127 uninfected; B) CCL-127 ZIKV infected; C) CRL-2266 uninfected; D) CRL-2266 ZIKV infected; E) CRL-2142 uninfected; F) CRL-2142 ZIKV infected; G) CRL-2267 uninfected; H) CRL-2267 ZIKV infected; I) CRL-2271 uninfected; J) CRL-2271 ZIKV infected; K) SMS-KCNR uninfected; L) SMS-KCNR ZIKV infected; M) JFEN uninfected; N) JFEN ZIKV infected; O) T268 uninfected, P) T-268 ZIKV infected. All the infected cells, except JFEN and T-268, are showing significant ZIKV infection induced changes of the neurons and showed neuronal proliferation, central hromatolysis, enlargement of the neuronal cell body, vacuolation within the cytoplasm, shortening or abnormal increase and thinning of axonal length, syncytia formation, and neurostimulations or selective neurocytotoxicity. (Adopted from BrandonW. Hughes et al.,) 


\section{MODELS TO STUDY PATHOGENESIS:}

Efforts to simulate the cellular manifestations of ZIKV infection during pregnancy, the subsequent microcephaly and other pathological conditions, demand the development and utilization of relevant model systems such as suitable cell lines and, importantly, animal models to study these mechanisms.

Kelli L. Barr et al [58] in their report suggest various cell lines for the effective analyses of ZIKV and Usutu viruses (USUVs). Meanwhile, Konstantin A. Tsetsarkin et al. [59] reports the development of a full length infectious cDNA clone of ZIKV, for studying viral pathogenesis and vaccine development. In addition, Marco Onorati et al., [60] report the establishment of Neuroepithelial stem cells (NES) for studying the neurotropism and microcephaly during ZIKV infections. Interestingly, Dawn M. Dudley et al., [61] from their current long term follow-up study, utilize and propose Rhesus macaques as model to study the mechanisms of ZIKV infections on human [FIGURE :13]. They suggest that this model could effectively simulate the pregnancy conditions in humans. Another group [62], in a similar work, report their study upon pregnant pigtail macaques to elucidate the fetal brain lesion followed by ZIKV infections [FIGURES:14-15].

Rossi SL et al, [63] in their Review details the necessity of using In vivo models to understand the mechanisms of ZIKV infections during pregnancy and those of the foetus. This Review also details some studies conducted upon Mice. Similar opinions were expressed in the short communications by $\mathrm{Na}-\mathrm{Na}$ Zhang et al [64]. In addition, Jonathan J. Miner et al., [29] utilized Rodent model to study the ophthalmic damages result from ZIKV infections. Using various receptor knockout mouse strains, they report that these infections could induce severe damages in the ocular systems and ZIKV RNA could be shed into the tears. In this study, mice mutant for Type 1 interferon receptor were selected and infected with ZIKV strains from French Polynesia and Brazil (termed 'Paraíba 2015') [ FIGURE:16]. This study supports the work of Valentine $G$ et al., [65] which analyzed various literature for the ZIKV induced neural and corneal damages. In addition, Jean-Baptiste Brault et al., [66] used mouse model to discriminate the neurotropism of various Flaviviruses.

Chick model [67] also is exploited to study the ZIKV infections during pregnancy in the first trimester, which is not possible in Rodent models. Infections in this model resulted in severe cardiac and neural damages much resembling the clinical conditions in humans. Aldo P et al., [68] from their study with human trophoblast cells, suggest that co-infection with Herpes simplex virus-2 (HSV-2), in addition to ZIKV infections, during the first trimester, could sensitize the placental cells for ZIKV entry.

Kellie Ann Jurado et al., [69] in their meticulous study with three distinct ZIKV strains, the prototype Uganda/African strain MR766 from 1947 (ZIKVMR766), the FSS13025 Cambodian/Asian isolate from 2010 (ZIKVCAM), and an Americas-derived virus isolated in 2016, MEX 2-81 (ZIKV ${ }^{M E X}$ ), suggest that placentalspecific macrophages and Hofbauer cells (HBCs) are the permissive entry sites for ZIKV to cross the maternal-foetal barrier. A similar study by Takako Tabata et al., [70] suggest that the compound Duramycin could reduce the placental infection of ZIKV. 


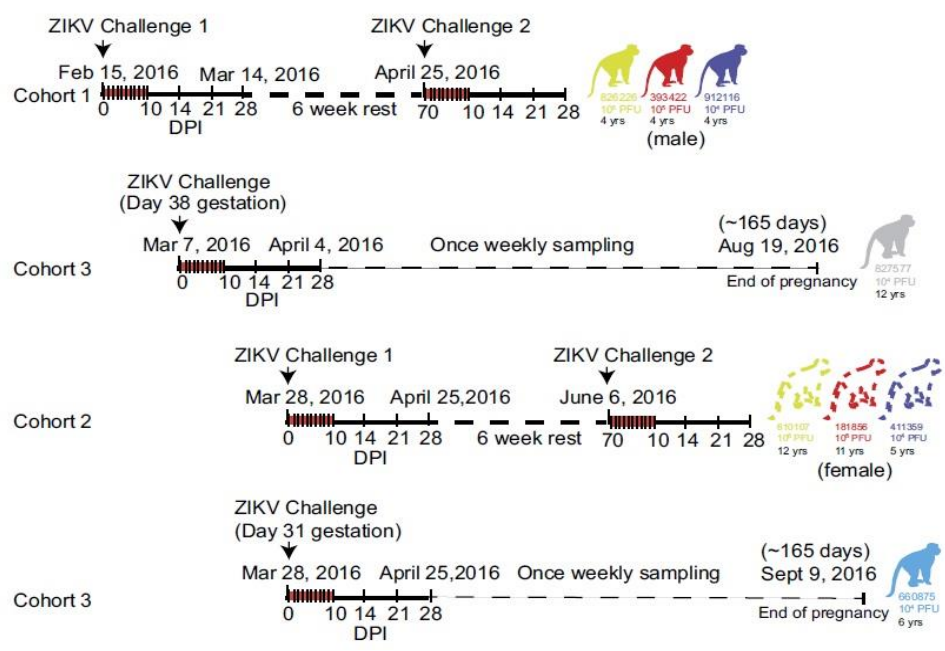

Figure :13. Schematic representation of the timeline of infection and sampling for each animal in the presented studies. Cohort 1 received the first ZIKV challenges and was then rested for 6 weeks before a rechallenge. For all studies, samples were collected daily for 10 days and then on 14, 21 and 28 days' post infection (d.p.i). as indicated by hashes in the timelines. Cohort 3 represents the two pregnant animals that were challenged on two different days. Both animals are currently in the once weekly sampling phase until the pregnancies come to term (B165 gestational days). Cohort 2 was a repeat experiment of cohort 1 that allowed for additional experiments and sample collection (for example, serum plaque infectivity) that were not feasible when we initiated cohort 1 studies. These animals are currently in a 6-week rest period and will be rechallenged on 6 June 2016. Ages of all animals are indicated under each macaque identification number. (Adopted from Dawn M. Dudley et al., 2016)
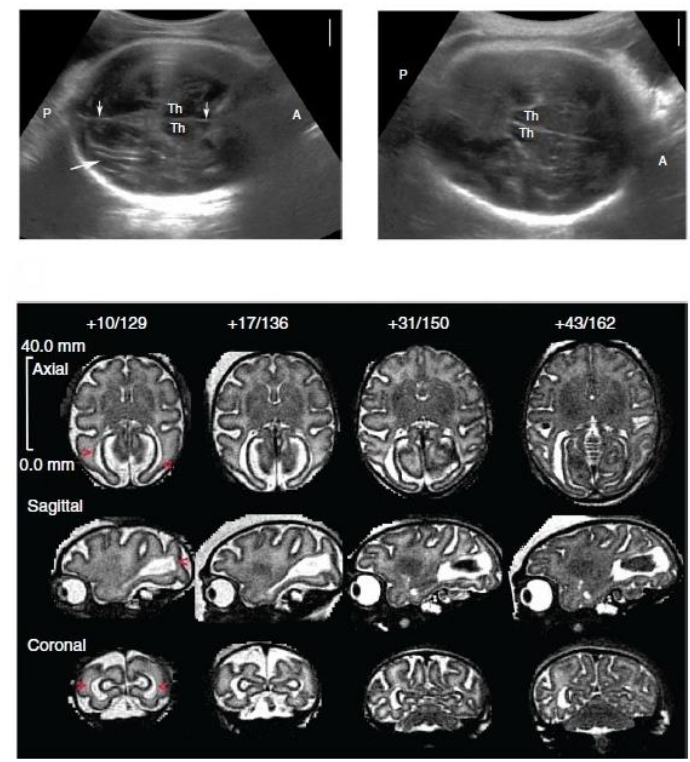

Figure:14. TOP. Right: An axial image of the fetal head obtained by ultrasound at $161 \mathrm{~d}$ gestation from the ZIKVinfected fetus. The large white arrow indicates a heterogeneous linear echogenic area in the posterior cerebral cortex on the right side. Other visible structures include the thalamus (Th) and falx (small white arrows). Labels indicate the anterior $(A)$ and posterior $(P)$ orientation. Left: An analogous image is shown for a control fetus at $163 \mathrm{~d}$ gestation.

BOTTOM. Serial axial (top), sagittal (middle) and coronal (bottom) MR images of the fetal brain in a ZIKV-infected pregnant pigtail macaque from 10 to $43 \mathrm{~d}$ after inoculation (129-162 d gestation). The red arrowheads indicate T2 hyperintense foci in the bilateral periventricular regions of the occipital-parietal brain. Numbers shown at the top of the image indicate 'time after inoculation (d)/time of gestation (d)'. (Adopted from Waldorf et al.,) 

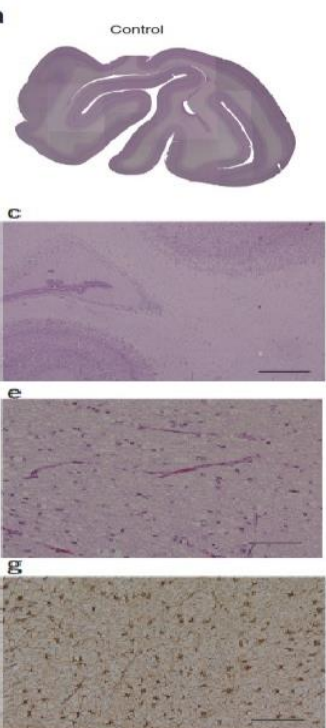
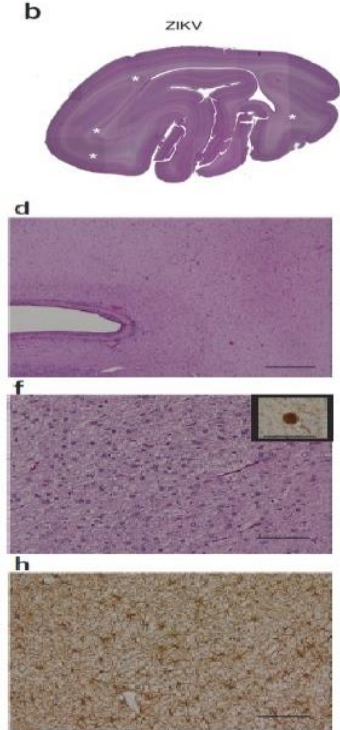

Figure:15. Neuropathology of the ZIKV-infected fetal brain and ZIKV RNA in fetal and dam tissues. (a-f) Representative H\&E-stained images of the brains from one ZIKV-infected fetus (b,d,f) and a control fetus (a,c,e) are shown. White asterisks (b) indicate pink bands of white matter hypoplasia and gliosis. Neurofilament staining (f, inset) indicates an axonal spheroid, which were only seen in the ZIKV-infected fetus. (g,h) Representative image from the entire brain section showing GFAP immunostaining in the control (g) or ZIKV-infected fetus (h). (Adopted from Waldorf et al.,)
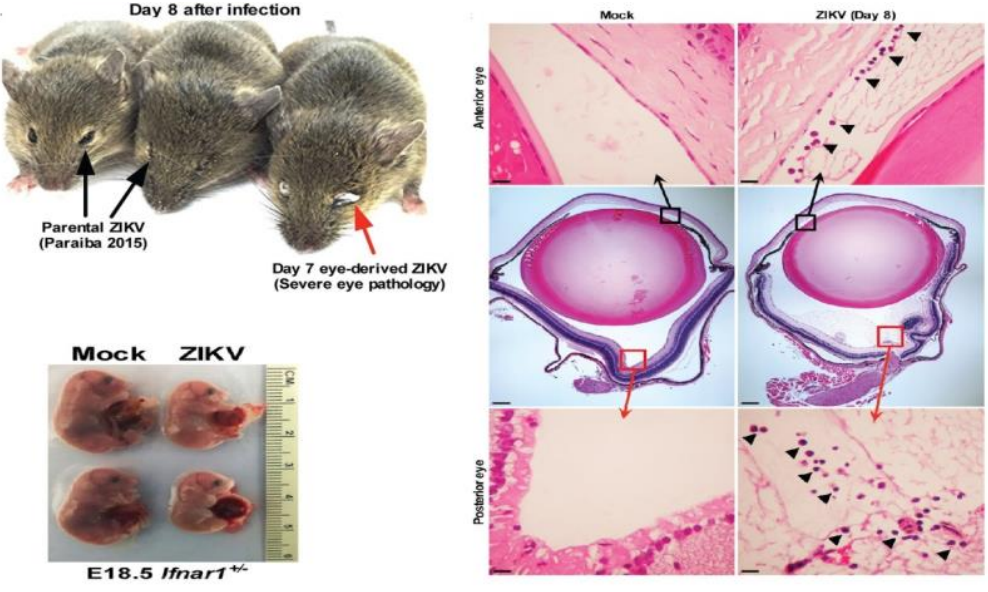

Figure:16. Left: TOP: A representative photograph demonstrating gross ocular pathology and exudate in mice inoculated with 104 FFUs of parental ZIKV Paraı'ba 2015 or eye-derived virus obtained from Ifnar 1__mice. BOTTOM. A representative photograph demonstrating the average size of mock- and ZIKV-infected Ifnar1+/fetuses on E18.5. Right. H\&E-stained eye sections from mock- (left panels) and ZIKV-infected animals on day 8 (right panels). Regions shown in higher magnification are indicated by a box and displayed in the upper and lower panels. Black arrowheads indicate inflammatory cell infiltrates in the anterior (upper panels) and posterior (lower panels) chambers of the eye. (Adopted from Jonathan J. Miner et al).

\section{POSSIBLE THERAPEUTIC INTERVENTIONS:}

Many compounds are reported to be effective anti-Zika viral, based on recent clinical trials, pathway assays, drug screenings and various bioinformatic approaches. Byler KG et al., [71] from their In-Silico docking studies report the possible usage of 43 phytochemicals to be used as ZIKV NS protein binders. Various NS proteins are reported to be sharing features and mediating crucial pathogenesis and evasion mechanisms among Flaviviruses [FIGURES: 17-18] [72-78]. 

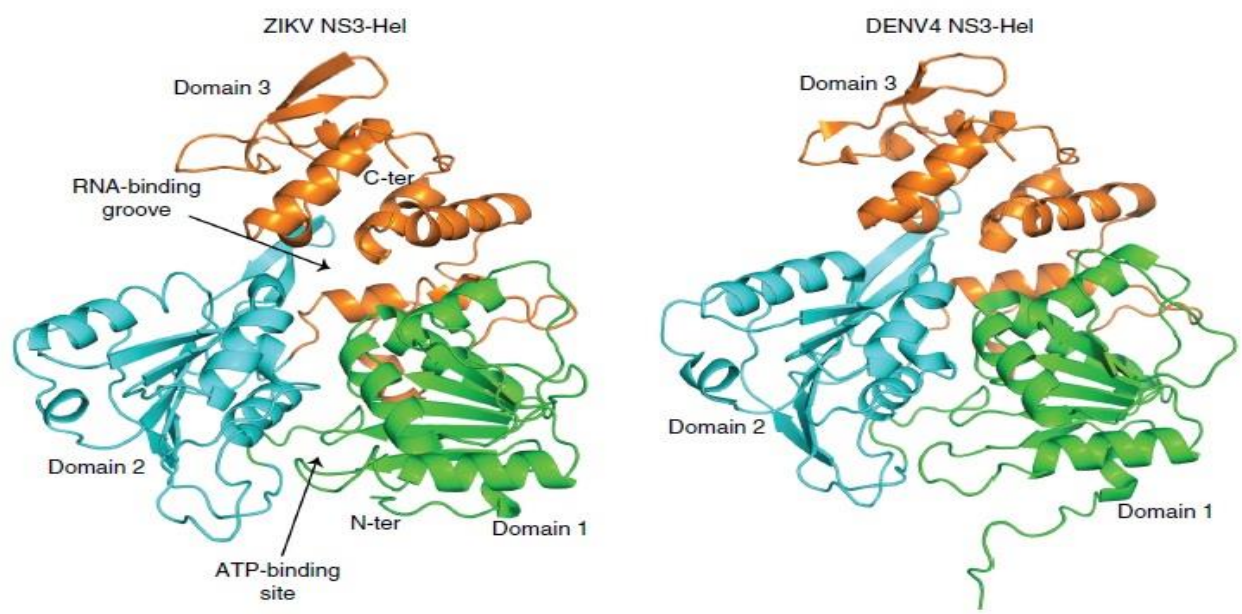

FIGURE:17. Structure comparison of ZIKV NS3-Hel with DENV4 NS3 helicase. Overall fold of ZIKV NS3-Hel residues 171-617 (left) and DENV4 helicase. (Adopted from Rinku Jain et al., 2016)
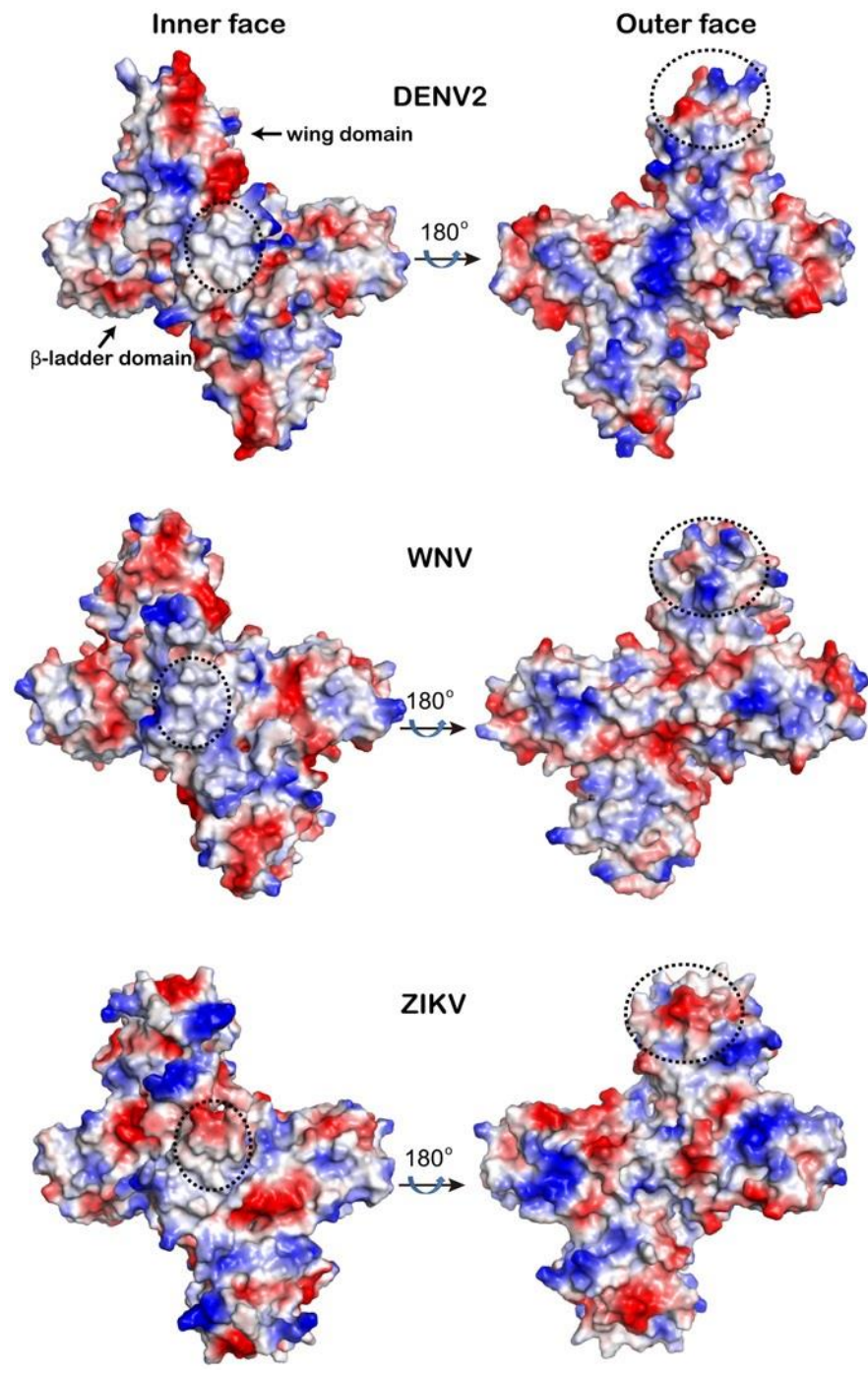

Figure:18. Variation in electrostatic surface potential of Flavivirus NS1proteins. Electrostatic surface views of NS1 from DENV2, WNV and ZIKV showing diverse characteristics on certain regions. Surfaces are colored by electrostatic potential at neutral pH from -2 kT (red) to +2 kT (blue) using PyMOL. (Adopted from Xiaoying Xu et al., 2016) 
In addition, Xu M et al. [79], from their drug screenings, report various FDA approved drugs such as Emricasan, Niclosamide, to be used as antiviral and Caspase-3 inhibitor compounds. Other FDA approved drugs such as Bortezomib, Mycophenolic acid Daptomycin also reported to be anti-ZIKV compounds [80]. The twoapproved anti -HCV drugs, IDX-184 and MK0608, also are reported to be optimally inhibiting the ZIKVpolymerase [81].
George Savidis et al., [82] reports that Interferoninducible transmembrane proteins (IFITMs) could block ZIKV replication in earlier stages [FIGURE:19]. IFN- $\beta$ along with IFN- $\gamma$ are also reported [83] to be effective ZIKV inhibitors in cell cultures. The nucleoside analogs such as 2'-C-methyladenosine and Sofosbuvir also could effectively block ZIKV induced cell death and relocate $\mathrm{pTBK1}$ (phosphorylated TANK binding kinase$1)$, a mechanism which could significantly abrogate the viral pathogenesis [60].

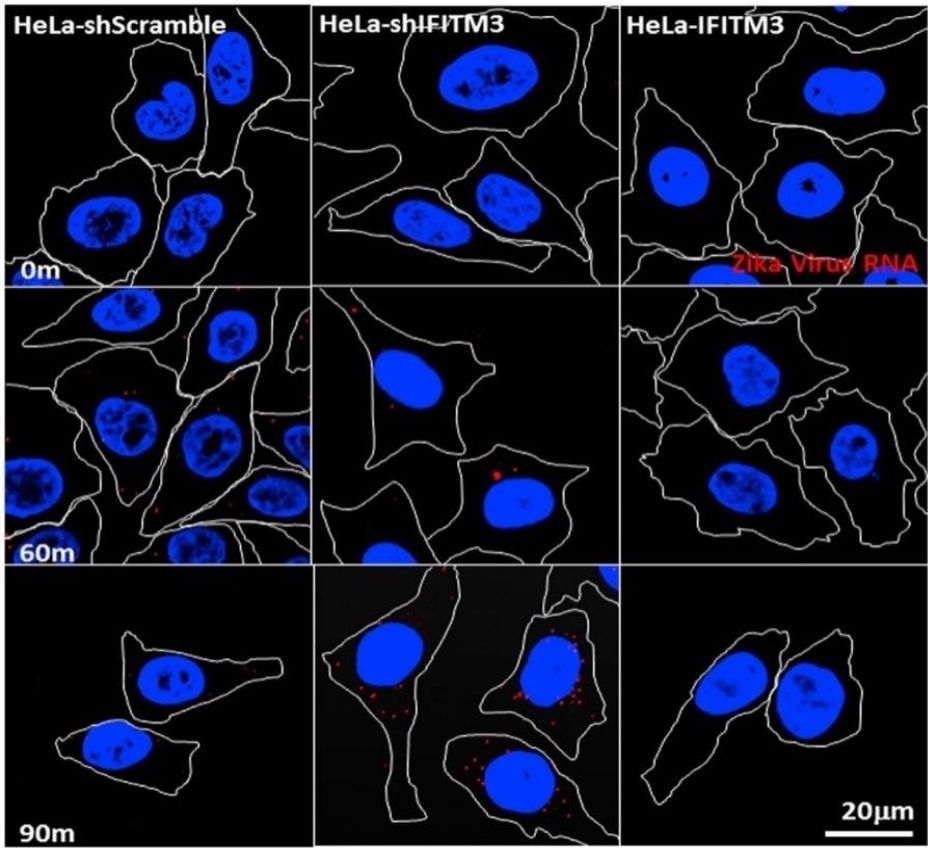

Figure:19 IFITM3 Inhibits the Early Replication of Zika Virus. HeLa cell lines were incubated on ice with ZIKV MR766 (Uganda, 1947) at an MOI of 100. At time zero, warm media was added and the cells were fixed, permeabilized, and stained for ZIKV RNA (red) and confocally imaged so as to capture a centrally located area within the cells. The nuclei of the cells were also stained for DNA with Hoechst 33342 dye (blue). White lines outline the cell boundaries based on DIC imaging. (Adopted from George Savidis et al.,2016)

Matthew T. Aliota et al., [84] reports a unique method to control the ZIKV infections via vectors. In their study, the Ifnar $\%$ C57BL/6 were mice infected with ZIKV. These mice have abrogated type 1-interferon signaling and are much vulnerable to infections and develop high viremia. They used Wolbachia, a maternally inherited intracellular bacterium and infected it upon the Colombian Ae.aegypti mosquito species (termed '(COL)wMel'). The mosquitoes were then fed on the Ifnar ${ }^{-1-}$ C57BL/6 mice for blood meal. Infection, Vector competency, Dissemination, and Transmission rates were compared between wild type (WT) and Colombian (COL) wMel vectors. The COLwMel subjects exhibited much less competence than the WT subjects. In addition, Govindarajan $M$ et al., [85] reports the usage of colloidal silver nanoparticles (AgNPs) to be used as possible larvicidal agents specifically against the ZIKV vector mosquitoes.

\section{CONCLUSION:}

One of the common features among all the countries with ZIKV epidemic, is that they are, for the most part, tropical with high humidity and rain fall. Almost no cases are reported in Europe, unless they are transmitted from travelers. So, the virulent ZIKV mutations are almost climate-dependent. We do have 
the clue that ZIKV pathogenesis are not unique either, as it mostly resembles that of DENV and its structural biology shares much similarity with other Flavi viruses. So, we are not in a complete blind-zone in this area. And most of the research ventures of developed countries of Europe and North America are focused upon Cancers, Heart diseases, Diabetes and Neurodegenerative diseases. Hence, in addition to CDC and $\mathrm{WHO}$, more immediate international efforts are needed to recognize and work on these rapid epidemics such as that of SARS, DENV, Ebola Virus and, currently, ZIKV, to contain and reduce the global mortality rates.

\section{REFERENCES:}

1. Dick GW, Kitchen SF, Haddow AJ. Zika virus. I. Isolation and serological specificity. Trans R Soc Trop Med Hyg. 1952; 46(5): 509-20.

2. Mac Namara FN. Zika virus: a report on three cases of human infection during an epidemic of jaundice in Nigeria. Trans R Soc Trop Med Hyg 1954; 48: 139-45.

3. Chee Fu Yung, Chia Yin Chong, Kee Thai Yeo et al., Zika Virus: An Evolving Public Health Threat, Annals Academy of Medicine, 2016, Vol. 45 No. 4.

4. Hee-Chang Jang, Wan Beom Park, Uh Jin Kim et al., First Imported Case of Zika Virus Infection into Korea, J Korean Med Sci 2016; 31: 1173-1177.

5. Ardath Grills, Stephanie Morrison, Bradley Nelson et al., Projected Zika Virus Importation and Subsequent Ongoing Transmission after Travel to the 2016 Olympic and Paralympic Games - Country-Specific Assessment, July 2016, Morbidity and Mortality Weekly Report, 2016, Vol. 65, No. 28.

6. Shadgan B, Pakravan A, Zaeimkohan H. Zika and Rio Olympic Games. Current sports medicine reports. 2016,15(4):298-300.

7. Boccolini D, Toma L, Di Luca M et al., Experimental investigation of the susceptibility of Italian Culex pipiens mosquitoes to Zika virus infection. Euro surveillance: European communicable disease bulletin. 2016, 21(35).

8. Amraoui $F$, Atyame-Nten C, Vega-Rúa A et al., Culex mosquitoes are experimentally unable to transmit Zika virus. Euro surveillance: European communicable disease bulletin. 2016,21(35).

9. Rosilainy Surubi Fernandes, Stéphanie Silva Campos, Anielly Ferreira-de-Brito, Culex quinquefasciatus, from Rio de Janeiro Is Not Competent to Transmit the Local Zika

Virus, PLoS Neglected Tropical Diseases,2016. 10(9).
10. Guo XX, Li CX, Deng YQ et al., Culex pipiens quinquefasciatus: a potential vector to transmit Zika virus. Emerging Microbes and Infections. 2016,5(9).

11. Davidson A, Slavinski S, Komoto $K$ et al., Suspected Female-to-Male Sexual Transmission of Zika Virus New York City, Morbidity and Mortality Weekly Report ,2016;65(28):716-7.

12. Richard B. Brooks, Maria Paz Carlos, Robert A. Myers et al., Likely Sexual Transmission of Zika Virus from a Man with No Symptoms of Infection - Maryland, 2016, Morbidity and Mortality Weekly Report, 2016, Vol. 65, No. 34.

13. Iara J.F. Motta, Bryan R. Spencer, Suely G. Cordeiro da Silva et al., Evidence for Transmission of Zika Virus by Platelet Transfusion, The New England Journal of Medicine, 2016.

14. Matthew J. Kuehnert, Sridhar V. Basavaraju, Robin R. Moseley et al., Screening of Blood Donations for Zika Virus Infection - Puerto Rico, April 3-June 11, 2016, Morbidity and Mortality Weekly Report, 2016, Vol. 65, No. 24.

15. Kristi L. Koenig, Abdulmajeed Almadhyan, Michael J. Burns, Identify-Isolate-Inform: A Tool for Initial Detection and Management of Zika Virus Patients in the Emergency Department, Western Journal of Emergency Medicine, 2016, Volume 17, No. 3.

16. Arias A, Torres-Tobar L, Hernández $G$ et al., GuillainBarré syndrome in patients with a recent history of Zika in Cúcuta, Colombia: A descriptive case series of 19 patients from December 2015 to March 2016, Journal of critical care. 2016, 37:19-23.

17. Emilio Dirlikov,Chelsea G. Major, Marrielle Mayshack et al., Guillain-Barré Syndrome During Ongoing Zika Virus Transmission - Puerto Rico, January 1-July 31, 2016, Morbidity and Mortality Weekly Report, 2016,Vol. 65, No. 34.

18. Muñoz LS, Barreras P, Pardo CA, Zika Virus-Associated Neurological Disease in the Adult: Guillain-Barré Syndrome, Encephalitis, and Myelitis, Seminars in reproductive medicine. 2016.

19. Thais dos Santos, Angel Rodriguez, Maria Almiron et al., Zika Virus and the Guillain-Barré Syndrome - Case Series from Seven Countries, The New England Journal of Medicine, 2016.

20. Mariana C. Leal, Lilian F. Muniz, Tamires S.A. Ferreira et al., Hearing Loss in Infants with Microcephaly and Evidence of Congenital Zika Virus Infection - Brazil, November 2015-May 2016, Morbidity and Mortality Weekly Report, 2016, Vol. 65, No. 34.

21. Viroj Wiwanitkit, Heart rate and blood pressure in Zika virus infection: Findings? Indian Heart Journal, $2016,168,380$. 
22. Beuy Joob, Viroj Wiwanitkit, Cardiac problem because of Zika virus infection: a possibility, Anatolian Journal of Cardiology, 2016; 16: 452-6.

23. Anthony R. Mawson, Pathogenesis of Zika VirusAssociated Embryopathy, BioResearch Open Access, 2016, Volume 5.1.

24. Ashutosh Kumar, Himanshu. N.Singh, Vikas Pareek et al., A Possible Mechanism of Zika Virus Associated Microcephaly: Imperative Role of Retinoic Acid Response Element (RARE) Consensus Sequence Repeats in the Viral Genome, Frontiers in Human Neuroscience, 2016,Volume10.

25. Bruno R. de Carvalho, Paulo F. Taitson, Karina S. A. G. Brandão et al., Reproductive planning in times of Zika: getting pregnant or delaying plans? The opinion of the Brazilian Society of Assisted Reproduction Committee - a basis for a bioethical discussion, SBRA Assisted Reproduction 2016;20(3):159-164.

26. Burke A, Moreau C. Family Planning and Zika Virus: The Power of Prevention. Seminars in Reproductive Medicine. 2016.

27. Abigail R.A. Aiken, James G. Scott, Rebecca Gomperts et al., Requests for Abortion in Latin America Related to Concern about Zika Virus Exposure, New England Journal of Medicine, 2016, 375;4.

28. Emanuele Nicastri, Concetta Castilletti, Pietro Balestra, Zika Virus Infection in the Central Nervous System and Female Genital Tract [Letter]. Emerging Infectious Disease journal. 2016, Dec.

29. Miner JJ, Sene A, Richner JM et al. Zika Virus Infection in Mice Causes Panuveitis with Shedding of Virus in Tears, Cell Reports, 2016;1-11.

30. Debora Ferreira Barreto-Vieira, Ortrud Monika Barth, Marcos Alexandre Nunes da Silva et al., Ultrastructure of Zika virus particles in cell cultures, Mem Inst Oswaldo Cruz, Rio de Janeiro, 2016, Vol. 111(8): 532534.

31. Rémi N Charrel, Isabelle Leparc-Goffart, Suzan Pas et al., Background review for diagnostic test development for Zika virus infection, Bull World Health Organ 2016;94:574-584.

32. Xu MY, Liu SQ, Deng CL et al., Detection of Zika virus by SYBR green one-step real-time RT-PCR. Journal of Virological Methods. 2016, 236:93-7.

33. Jinzhao Song, Michael G. Mauk, Brent A. Hackett et al., Instrument-Free Point-of-Care Molecular Detection of Zika Virus, Analytical Chemistry. 2016, 88, 7289-7294.

34. Bo Tian, Zhen Qiu , Jing $M$ et al., Attomolar Zika virus oligonucleotide detection based on loop-mediated isothermal amplification and $A C$ susceptometry, Biosensors and Bioelectronics, 2016, 86: 420-425.

35. Calvo EP, Sánchez-Quete F, Durán $S$ et al., Easy and inexpensive molecular detection of dengue, chikungunya and zika viruses in febrile patients. Acta Tropica. 2016. 163:32-7.

36. Lalita Priyamvada, Kendra M. Quicke, William H. Hudson et al., Human antibody responses after dengue virus infection are highly cross-reactive to Zika virus, Proceedings of National Academy of Scienes, 2016, vol. 113, No. 28.

37. Myrna C. Bonaldo, leda P. Ribeiro, Noemia S. Lima et al., Isolation of Infective Zika Virus from Urine and Saliva of Patients in Brazil, PLOS Neglected Tropical Diseases, 2016.

38. Dhiraj Acharya, Pradip Bastola,, Linda Le et al., An ultrasensitive electrogenerated chemiluminescencebased immunoassay for specific detection of Zika virus, Scientific Reports.2016, 6, 32227.

39. Weifeng Shi, Zhenjie Zhang, Cheng Ling et al., Increasing genetic diversity of Zika virus in the Latin American outbreak, Emerging Microbes \& Infections, 2016, 5.

40. Jan-Hendrik Trösemeier, Didier Musso, Johannes Blümel et al., Genome Sequence of a Candidate World Health Organization Reference Strain of Zika Virus for Nucleic Acid Testing, Genome Announcements, 2016, Volume 4 Issue 5.

41. Meghan May, Ryan F. Relich, A Comprehensive Systems Biology Approach to Studying Zika Virus, PLos ONE, 2016

42. Sang-Im Yun, Byung-Hak Song, Jordan C. Frank et al., Complete Genome Sequences of Three Historically Important, Spatiotemporally Distinct, and Genetically Divergent Strains of Zika Virus: MR-766, P6-740, and PRVABC-59, Genome Announcements,2016, Volume 4 Issue 4.

43. G. Piorkowski, P. Richard, C. Baronti et al., Complete coding sequence of Zika virus from Martinique outbreak in 2015, New Microbes and New Infections 2016; 11: 52-53.

44. Formijn van Hemert and Ben Berkhout, Nucleotide composition of the Zika virus RNA genome and its codon usage, Virology Journal (2016) 13:95.

45. Cristina J, Fajardo A, Soñora $M$ et al., A detailed comparative analysis of codon usage bias in Zika virus. Virus Research. 2016; 223:147-52.

46. Zichen Wang, Avi Ma'ayan, An open RNA-Seq data analysis pipeline tutorial with an example of reprocessing data from a recent Zika virus study [version 1; referees: 3 approved], F1000Research, 2016, 5:1574.

47. Sandeep Chakraborty, MEPPitope: spatial, electrostatic and secondary structure perturbations in the post-fusion Dengue virus envelope protein highlights known epitopes and conserved residues in 
the Zika virus [version 1; referees: 3 approved], F1000Research, 2016, 5:1150.

48. Dikhit MR, Ansari MY, Vijaymahantesh et al., Computational prediction and analysis of potential antigenic CTL epitopes in Zika virus: A first step towards vaccine development, Infection, Genetics and Evolution:Journal of Molecular Epidemiology and Evolutionary Genetics in Infectious diseases. 2016; 45:187-197.

49. Alam A, Ali $S$, Ahamad $S$ et al., From ZikV genome to vaccine: in silico approach for the epitope-based peptide vaccine against Zika virus envelope glycoprotein, Immunology, 2016, Aug 3.

50. Zhao H, Fernandez E, Dowd KA et al., Structural Basis of Zika Virus-Specific Antibody Protection, Cell, 2016;166(4).

51. J. A. Swanstrom, J. A. Plante, K. S. Plante et al., Dengue Virus Envelope Dimer Epitope Monoclonal Antibodies Isolated from Dengue Patients Are Protective against Zika Virus,mbio, 2016,Volume 7, Issue 4.

52. Victor Satler Pylro, Francislon Silva Oliveira, Daniel Kumazawa Morais et al., ZIKV - CDB: A Collaborative Database to Guide Research Linking SncRNAs and ZIKA Virus Disease Symptoms, PLoS Neglected Tropical Diseases .2016,10(6).

53. Rolfe AJ, Bosco DB, Wang J et al., Bioinformatic analysis reveals the expression of unique transcriptomic signatures in Zika virus infected human neural stem cells. Cell and Bioscience. 2016;1-13.

54. Hanners NW, Eitson JL, Usui N et al. Western Zika Virus in Human Fetal Neural Progenitors Persists Long Term with Partial Cytopathic and Limited Immunogenic Effects. Cell Reports .2016;15(11):2315-22.

55. Zhang F, Hammack C, Ogden SC et al. Molecular signatures associated with ZIKV exposure in human cortical neural progenitors. Nucleic Acids Research, 2016;1-11.

56. Li H, Saucedo-Cuevas L, Regla-Nava JA et al., Zika Virus Infects Neural Progenitors in the Adult Mouse Brain and Alters Proliferation, Cell Stem Cell. 2016.

57. Hughes BW, Addanki KC, Sriskanda AN et al., Infectivity of Immature Neurons to Zika Virus: A Link to Congenital Zika Syndrome. EBioMedicine 2016; 10:65-70.

58. Barr KL, Anderson BD, Prakoso $D$ et al., Working with Zika and Usutu Viruses In Vitro. PLoS Neglected Tropical Diseases.2016;1-13.

59. Tsetsarkin KA, Kenney $\mathrm{H}$, Chen $\mathrm{R}$ et al., A Full-Length Infectious cDNA Clone of Zika Virus from the 2015 Epidemic in Brazil as a Genetic Platform for Studies of Virus-Host.mBio. 2016;7(4):1-8.

60. Onorati M, Li Z, Liu F et al., Zika Virus Disrupts PhosphoTBK1 Localization and Mitosis in Human
Neuroepithelial Stem Cells and Radial Glia. Cell Reports. 2016;1-17.

61. Dudley DM, Aliota MT, Mohr ELet al. A rhesus macaque model of Asian-lineage Zika virus infection. Nature Communications. 2016:1-9.

62. Waldorf KMA, Stencel-baerenwald JE, Vornhagen J et al. Fetal brain lesions after sub - cutaneous inoculation of Zika virus in a pregnant nonhuman primate. Nature Medicine. 2016:1-6.

63. Rossi SL, Vasilakis N. Modeling Zika Virus Infection in Mice. Cell Stem Cell. $2016 ; 19(1): 4-6$

64. Na-Na Zhang, Min Tian, Yong-Qiang Deng, Characterization of the contemporary Zika virus in immunocompetent mice [Letter], Human Vaccines \& Immunotherapeutics,2016.

65. Valentine G, Marquez L, Pammi M. Zika VirusAssociated Microcephaly and Eye Lesions in the Newborn. Journal of the Paediatric Infectious diseases Society _ 2016.5(3):323-8.

66. Brault J, Khou C, Basset J et al. Comparative Analysis Between Flaviviruses Reveals Specific Neural Stem Cell Tropism for Zika Virus in the Mouse Developing Neocortex. E Bio Medicine .2016;10:71-6.

67. Goodfellow F, Tesla B, Simchick G. Zika Virus Induced Mortality and Microcephaly in Chicken Embryos. Stem cells and Development. 2016.

68. Aldo P, You Y, Szigeti K. HSV-2 enhances ZIKV infection of the placenta and induces apoptosis in first-trimester trophoblast cells. American Journal of Reproductive Immunology. 2016.

69. Kellie Ann Jurado, Michael K. Simoni, Zhonghua Tang, Zika virus productively infects primary human placenta-specific macrophages, JCl Insight. 2016.

70. Tabata T, Petitt M, Puerta-guardo $\mathrm{H}$ et al. Zika Virus Targets Different Primary Human Placental Cells, Suggesting Two Routes for Vertical Transmission. Cell Host \& Microbe. 2016;20(2):155-66.

71. Byler KG, Ogungbe IV, Setzer WN. In-silico screening for anti-Zika virus phytochemicals. Journal of Molecular Graphics and Modelling. 2016.69:78-91.

72. Sironi $M$, Forni $D$, Clerici $M$ et al., Nonstructural Proteins Are Preferential Positive Selection Targets in Zika Virus and Related Flaviviruses. PLoS Neglected Tropical Diseases,2016;1-18.

73. Jain R, Coloma J, García-sastre A. Structure of the NS3 helicase from Zika virus. Nature Publishing Group. 2016;23(8):752-4.

74. Lei J, Hansen G, Nitsche C et al., Crystal structure of Zika virus NS2B-NS3 protease in complex with a boronate inhibitor. Science. 2016.353(6298):503-5.

75. Brown WC, Akey DL, Konwerski JR et al., Extended surface for membrane association in Zika virus NS1 
structure. Nature Structural and Molecular Biology. 2016. 23(9):865-7.

76. Rastogi $M$, Sharma N, Singh SK. Flavivirus NS1: A Multifaceted enigmatic viral protein. Virology Journal; 2016;1-10.

77. Xu X, Song H, Qi J et al. Contribution of intertwined loop to membrane association revealed by Zika virus fulllength NS 1 structure. The EMBO Journal,2016;1-9.

78. Tian H, Ji X, Yang $X$ et al. Structural basis of Zika virus helicase in recognizing its substrates. Protein Cell. 2016;7(8):562-70.

79. Xu M, Lee EM, Wen $Z$ et al., Identification of smallmolecule inhibitors of Zika virus infection and induced neural cell death via a drug repurposing screen. Nature Medicine. 2016.

80. Barrows NJ, Campos RK, Powell ST et al., A Screen of FDA-Approved Drugs for Inhibitors of Zika Virus Infection. Cell Host Microbe. 2016.20(2):259-70.
81. Elfiky AA. Zika viral polymerase inhibition using antiHCV drugs both in market and under clinical trials. Journal of Medical Virology. 2016.

82. Savidis G, Perreira JM, Portmann JM et al. Report the IFITMs Inhibit Zika Virus Replication. Cell Reports .2016, 15(11):2323-30.

83. Contreras D, Arumugaswami V, Zika Virus Infectious Cell Culture System and the In Vitro Prophylactic Effect of Interferons, Journal of Visualized Experiments, 2016 Aug 23;(114).

84. Aliota MT, Peinado SA, Velez ID et al., The w Mel strain of Wolbachia Reduces Transmission of Zika virus by Aedes aegypti. Nature Publishing Group; 2016:1-7.

85. Govindarajan M, Kadaikunnan S, Alharbi NS et al., Single-step biological fabrication of colloidal silver nanoparticles using Hugonia mystax: larvicidal potential against Zika virus, dengue, and malaria vector mosquitoes. Artificial Cells, Nanomedicine and Biotechnology. 2016:1-9. 